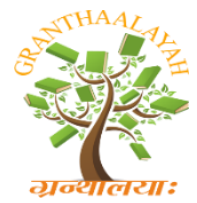

\author{
INTERNATIONAL JOURNAL OF RESEARCH - \\ GRANTHAALAYAH \\ A knowledge Repository
}

Science

\title{
PHYTOCHEMICAL SCREENING AND NUTRIENT CONTENT ANALYSIS OF STEM AND ROOT OF TRIDAX PROCUMBENS LINN
}

\author{
Thiyagarajan Bharathi ${ }^{1}$, Rajangam Udayakumar *1 \\ ${ }^{1}$ Post Graduate and Research Department of Biochemistry, Government Arts College \\ (Autonomous), Kumbakonam-612 002, Tamil Nadu, India
}

\begin{abstract}
The medicinal plant Tridax procumbens belongs to the family of Asteraceae was selected for this study based on medicinal value. It was collected from the campus of Government Arts College (Autonomous), Kumbakonam - 612 002, Tamilnadu, India during the months between March and June 2017. The stem and root of Tridax procumbens were separated, cleaned and dried under shade. The dried plant materials were then ground well into powder. The $20 \mathrm{~g}$ of powder of stem and root was soaked in $200 \mathrm{ml}$ of benzene and diethyl ether individually and they were kept at room temperature for 48 hours. After that, the mixture was filtered through a clean muslin cloth and the extracts were concentrated using evaporator at $37^{\circ} \mathrm{C}$ till the sticky mass was obtained. The phytocompounds alkaloids, flavonoids, saponins, terpenoids, phenolic compounds, tannins, triterpenoids, steroids, quinones, glycosides and coumarins were analysed in benzene and diethyl ether extracts of stem and root of Tridax procumbens by qualitatively. Phytochemical screening showed that the presence of all above mentioned phytocompounds in benzene and diethyl ether extracts of stem and root of Tridax procumbens except steroids, saponins and glycosides. The content of carbohydrates, protein and vitamin $\mathrm{C}$ in the fresh sample of stem and root were analysed by quantitatively.
\end{abstract}

Keywords: Phytocompounds; Nutrient Content; Root; Stem; Tridax Procumbens.

Cite This Article: Thiyagarajan Bharathi, and Rajangam Udayakumar. (2019). "PHYTOCHEMICAL SCREENING AND NUTRIENT CONTENT ANALYSIS OF STEM AND ROOT OF TRIDAX PROCUMBENS LINN." International Journal of Research Granthaalayah, 7(8), 470-477. https://doi.org/10.29121/granthaalayah.v7.i8.2019.701.

\section{Introduction}

India is a country with a vast reserve of natural resources and a rich history of traditional medicine. The different systems of medicinal usage practiced in India like Ayurveda, Siddha, Unani, Amchi, Homoeopathy and local health traditions, utilize a large number of plants for treatment of human and animal diseases and these plants are called as medicinal plants [1]. India officially recognizes over 3000 plants for their medicinal value. It is generally estimated that over 6000 plants in India are used in traditional, folk and herbal medicine. 
Tridax procumbens is a common medicinal herb used by ethno-medical practitioners, belonging to the family Asteraceae. The plant is a procumbent herb and is valued for its pharmaceutical properties [2]. The plant is native of tropical America and naturalized in tropical Asia, Africa, Australia, and India. It is a wild herb distributed throughout India. Tridax procumbens is a small perennial herb having short, hairy blade like leaves. Corolla is yellow in color. It is a common weed grows in open places, coarse textured soils of tropical regions, sunny dry localities, fields, waste areas, meadows and dunes. All plants produce chemical compounds as part of their normal metabolic activities. These phytochemicals are divided into primary metabolites such as sugars, protein and fats, which are found in all plants; and secondary metabolites which are found in a smaller range of plants serving a more specific function. For example, some secondary metabolites are toxins used to deter predation and others are pheromones used to attract insects for pollination [3]. Photosynthesis and pentose pathway together pools the phosphate group present in the sugar molecules of plants which leads to glycolysis process and it is accounted for producing many of phytochemicals of plants, such as, shikimic acid, proteins, aliphatic and aromatic acids, mevalonic acids, fatty acids, flavonoids, terpinoids, steroids etc. There are lots of medicinal plants which contain a number of phytochemicals and those phytochemicals are used in medicine to treat various kinds of diseases.

Phytochemical screening of the leaves of Tridax procumbens revealed the presence of alkaloids, carbohydrates, tannins, saponins, phenols, flavonoids, anthraquinones and cardiac glycosides. Leaves are also used for the treatment of bronchial catarrh, dysentery, diarrhoea and for the restoration of hairs [4]. The leaf juice possesses antiseptic, insecticidal and antiparasitic properties. It is also used to check hemorrhage from cuts, bruises and wounds [5]. Leaf extracts can be used to treat infectious skin diseases in folk medicines. It is well known aurvedic medicine for liver disorders besides gastritis and heart burn [6]. Based on the available literature, there are many plants used as medicine among these, Tridax procumbens was selected for this study based on the medicinal importance. Many reports are available including pharmacological activities of Tridax procumbens. But, there are no studies on phytochemical screening of stem and root of Tridax procumbens using GC-MS analysis. So the present study was aimed to analyze the phytochemical constituents and nutrient contents like carbohydrates, proteins and vitamin $\mathrm{C}$ in stem and root of Tridax procumbens.

\section{Materials and Methods}

\section{Details About the Medicinal Plant}

Tridax procumbensis an important medicinal plant and belongs to the family Asteraceae. The classification of Tridax procumbens is as follows: Kingdom - Plantae, Subkingdom Tracheobionta, Division - Magnoliophyta, Class - Magnoliopsida, Subclass - Asteridae, Order Asterales, Family - Asteraceae, Genus - Tridax and Species - T. procumbens. The vernacular names of Tridax procumbensis as follows: Tamil - Vettukaayapoondu, English - Tridax daisy, Sanskrit - Jayantiveda, Marathi - Kambarmodi, Hindi- Ghamra, Kannada - Jayanthi and Telugu Gaddichemanthi. The leaf, flower, stem and root of Tridax procumbens were used for the medicinal purposes. 


\section{Plant Description}

Annual or biennial somewhat patently hispid herbs. Stem branched, creeping at base, sub erect or trailing above. Leaves are ovate-lanceolate, or elliptic-rhomboid, with a cuneate base, obtuse or sub acute, coarsely serrate or lobed, patently hispid, $2.5-7 \mathrm{~cm}$ long. Heads are solitary, $1.2-1.5 \mathrm{~cm}$ across, on erect, 10-30 cm long peduncle. Marginal flowers 5-6 with pale yellow, $0.3 \mathrm{~cm}$ long ligules; disc flowers bright yellow. It has a tap root system.

\section{Collection of Plant Materials}

The selected plant Tridax procumbens was collected from the campus of Government Arts College (Autonomous), Kumbakonam - 612 002, Tamilnadu, India during the months between March and June 2017. The plant was identified by Dr. R. Murugan, Assistant Professor and Head, Department of Botany, Government Arts College (Autonomous), Kumbakonam - 612 002, Tamilnadu, India.

\section{Preparations of Plant Extracts}

From the collected plant, the parts stem and root of Tridax procumbens were separated, washed and dried under shade for 10 days at room temperature. The plant sample was powdered by using grinder. The powdered plant material was stored in an air tight container until the time of use. The $20 \mathrm{~g}$ powder of stem and root of Tridax procumbens was soaked in $200 \mathrm{ml}$ of benzene and diethyl ether separately and they were kept in room temperature for 48 hours. After that, the mixture was filtered through a clean muslin cloth and then the extracts were concentrated and dried in evaporator at $37^{\circ} \mathrm{C}$ and then sticky mass was obtained. The dried extracts were stored at $4^{\circ} \mathrm{C}$ until the process of phytochemical analysis.

\section{Preliminary Phytochemical Screening}

The phytoconstituents present in the benzene and diethyl ether extracts of stem and root of Tridax procumbens were analyzed qualitatively by using standard procedures $[7,8,9]$.

\section{Test for Alkaloids}

About $2 \mathrm{ml}$ of extract was taken and added $2 \mathrm{ml}$ of concentrated HCL and then Mayer's reagent was added drop wise. The formation of white precipitate indicates the presence of alkaloids.

\section{Test for Flavonoids}

The extract of $0.1 \mathrm{ml}$ was taken and made up to $5 \mathrm{ml}$ with distilled water, after which $0.3 \mathrm{ml}$ of sodium nitrate was added and incubated for $5 \mathrm{mins}$ at room temperature and then added $3 \mathrm{ml}$ of $10 \%$ aluminium chloride which is incubated for $6 \mathrm{mins}$ at room temperature. Finally, $2 \mathrm{ml}$ of sodium hydroxide $(\mathrm{NaOH})$ was added. The formation of yellow color indicates the presence of flavonoids.

\section{Test for Saponins}

About $2 \mathrm{ml}$ of filtrate was mixed with $1 \mathrm{ml}$ of distilled water and shaken vigorously for about 3 seconds and it was allowed to stand for few mins and then added 3 drops of olive oil and shaken vigorously. Formation of emulsion indicates the presence of saponins.

\section{Test for Terpenoids}

About $1 \mathrm{ml}$ of the extract and $2 \mathrm{ml}$ of chloroform was taken and followed by the addition of $5 \mathrm{ml}$ of concentrated $\mathrm{H}_{2} \mathrm{SO}_{4}$ along the sides of the test tubes. Formation of a reddish brown coloration in the interphase indicates the presence of terpenoids. 


\section{Test for Phenolic Compounds}

To $1 \mathrm{ml}$ of extract, $1 \mathrm{ml}$ of Iron (III) chloride was added and mixed well. A deep blue green color was formed which indicates the presence of phenolic compounds.

\section{Test for Triterpenoids}

A $10 \mathrm{mg}$ of extract was dissolved in $1 \mathrm{ml}$ of acetic anhydride and then added $2 \mathrm{ml}$ of concentrated $\mathrm{H}_{2} \mathrm{SO}_{4}$. Formation of reddish violet color indicates the presence of triterpenoids.

\section{Test for Quinones}

To $2 \mathrm{ml}$ of plant extract, $1 \mathrm{ml}$ of concentrated $\mathrm{H}_{2} \mathrm{SO}_{4}$ was added. Formation of red color indicates the presence of quinones.

\section{Test for Steroids}

To $10 \mathrm{mg}$ of plant extract, $2 \mathrm{ml}$ of acetic anhydride and followed by $2 \mathrm{ml}$ of $\mathrm{H}_{2} \mathrm{SO}_{4}$ were added. Formation of violet or blue color indicates the presence of steroids.

\section{Test for Tannins}

To $1 \mathrm{ml}$ of the extract added $0.1 \%$ of ferric chloride solution and observed brownish green or a blueblack coloration which indicates the presence of tannins.

\section{Test for Glycosides}

About $1 \mathrm{ml}$ of extract was treated with $2 \mathrm{ml}$ of glacial acetic acid containing one drop of ferric chloride solution. This was underplayed with $1 \mathrm{ml}$ of concentrated sulphuric acid. A brown ring at the interface indicates deoxysugar which confirms the presence of cardenolides. A violet-green ring appearing below the brown ring in the acetic acid layer indicates the presence of glycosides.

\section{Test for Coumarins}

The extract was dissolved in methanol and then added alcoholic $\mathrm{NaOH}$. A yellow color appears which later disappears on addition of drops of concentrated $\mathrm{HCl}$ indicates the presence of coumarins.

\section{Estimation of Ascorbic Acid (vitamin C)}

The amount of ascorbic acid present in the plant sample was estimated by the method of 2, 6 dichlorophenol indophenol dye [10]. For this pipetted out $5 \mathrm{ml}$ of the working standard solution into $100 \mathrm{ml}$ conical flask and then added $10 \mathrm{ml}$ of $4 \%$ oxalic acid and titrated against dye. Extracted the sample (5g of sample) in $10 \mathrm{ml}$ of $4 \%$ oxalic acid and centrifuged. Pipetted out $5 \mathrm{ml}$ of this supernatant, then added $10 \mathrm{ml}$ of $4 \%$ oxalic acid and titrated against dye. End point was the appearance of pink color, which persisted for a few minutes. The amount of dye consumed was equivalent to the amount of ascorbic acid. The results were expressed as g per $100 \mathrm{~g}$ of tissue.

\section{Estimation of Carbohydrates}

The amount of carbohydrates present in the plant sample was estimated by anthrone method [11]. A $100 \mathrm{mg}$ of plant sample was taken into a boiling tube and hydrolyzed by kept it in a boiling water bath for three hours with $5 \mathrm{ml}$ of $2.5 \mathrm{~N}$ Hydrochloric acid and then cooled to room temperature. The neutralization of the solution was done by the addition of solid sodium carbonate till the effervescence ceased. Made up the volume to $100 \mathrm{ml}$ and centrifuged. The supernatant was collected and took $2 \mathrm{ml}$ aliquot for estimation. The aliquots of $0.2,0.4,0.6,0.8$ and $1 \mathrm{ml}$ of standard 
glucose solution were taken into the tubes and made up the volume to $2 \mathrm{ml}$ including the test with distilled water and then added $4 \mathrm{ml}$ of anthrone reagent in all tubes. Heated for eight minutes in a boiling water bath and cooled rapidly and read the green to dark green color at 630nm using spectrophotometer.

\section{Estimation of Protein by Lowry's Method}

The amount of protein present in the plant sample was estimated by Lowry's method [12]. A $500 \mathrm{mg}$ of the sample homogenized with $5 \mathrm{ml}$ of $10 \%$ tricholoroacetic acid and then added $1 \mathrm{ml}$ of water and it was coagulated. The samples were filtered and used the supernatant for protein estimation. The aliquots of $0.2,0.4,0.6,0.8$ and $1 \mathrm{ml}$ of working standard was pipetted out into different tubes. $0.2 \mathrm{ml}$ of the test sample was taken separately. Made up the volume to $1 \mathrm{ml}$ with distilled water all tubes. A separate tube with $1 \mathrm{ml}$ of water served as blank. Finally $4 \mathrm{ml}$ of alkaline copper reagent and $0.4 \mathrm{ml}$ of folin's reagent were added in all tubes. The blue color was developed after 15 min and then read at $620 \mathrm{~nm}$.

\section{Results and Discussion}

Traditional medicinal knowledge and its use for finding active chemical structures for medicine is necessary to have co-operative efforts between modern and traditional health workers and researchers. In developing countries, traditional medicine occupies a central place among rural communities but enough information is not available about the chemical composition and real biological possibilities of most of the plants traditionally in use [13].

In the present study, the qualitative phytochemical analysis was carried out in benzene and diethyl ether extracts of stem and root of Tridax procumbens and the results were summarized in Table 1. The qualitative phytochemical analysis of benzene and diethyl ether extracts of stem and root of Tridax procumbens showed that the presence of alkaloids, flavonoids, terpenoids, phenolic compounds, quinines, tannins, triterpenoids and coumarins except saponins, steroids and glycosides.

Table 1: Phytochemical screening of benzene and diethyl ether extracts of stem and root of Tridax procumbens

\begin{tabular}{|l|c|c|c|c|}
\hline \multirow{2}{*}{ Name of the phytoconstituent } & \multicolumn{5}{|c|}{ Name of the solvent extract } \\
\cline { 2 - 5 } & \multicolumn{2}{|c|}{ Benzene extract } & \multicolumn{2}{c|}{ Diethyl ether extract } \\
\cline { 2 - 5 } & Stem & Root & Stem & Root \\
\hline Alkaloids & + & + & + & + \\
\hline Flavonoids & + & + & + & + \\
\hline Saponins & - & - & - & - \\
\hline Terpenoids & + & + & + & + \\
\hline Phenolic compounds & + & + & + & + \\
\hline Triterpenoids & + & + & + & + \\
\hline Quinones & + & + & + & + \\
\hline Steroids & - & - & - & - \\
\hline Tannins & + & + & + & + \\
\hline Glycosides & - & - & - & - \\
\hline Coumarins & + & + & + & + \\
\hline
\end{tabular}

+ Present, - Absent 
The phytochemical determination may be useful in the detection of the bioactive compounds and bionutrient may lead to drug discovery and development. Phytochemicals to provide health benefit for human in way of macronutrients and micronutrients. The chemical that protect plant cells from environmental hazard such as pollution, stress, drought, UV exposure and pathogenic effect are called phytochemicals [14]. More than 4,000 phytochemicals have been investigated and catalogued.

Alkaloids are used as anaesthetic agent and are found in medicinal plants. Terpenoids can have medicinal properties such as anticarcinogenic, antimalarial, antimicrobial and diuretic activities. Terpenoids are also very important in attracting useful mites and consume the herbivorous insects [15].

Flavonoids are the most important plant pigments for flower coloration and as chemical messengers, physiological regulators, and cell cycle inhibitors [16]. Coumarin is a fragrant organic chemical compound in the benzopyrone chemical class, which is a colorless crystalline substance in its standard state. It is a natural substance found in many plants. Coumarins have shown some evidence of biological activity and have limited approval for few medical uses as pharmaceuticals, such as in the treatment of lymphedema [17].

Carbohydrates, protein and vitamin $\mathrm{C}$ were estimated in freshly collected stem and root of Tridax procumbens and the results were presented in Table 2 . The stem and root of Tridax procumbens contains carbohydrates $23 \pm 2.5 \mathrm{~g} / 100 \mathrm{~g}$ and $40 \pm 2.8 \mathrm{~g} / 100 \mathrm{~g}$, respectively. Protein content was determined in stem and root of Tridax procumbens as $12 \pm 1.6 \mathrm{~g} / 100 \mathrm{~g}$ and $11.6 \pm 1.9 \mathrm{~g} / 100 \mathrm{~g}$, respectively. Vitamin $\mathrm{C}$ content was also determined in stem and root of Tridax procumbens as $0.0368 \pm 0.87 \mathrm{~g} / 100 \mathrm{~g}$ and $0.0075 \pm 0.48 \mathrm{~g} / 100 \mathrm{~g}$, respectively.

Table 2: The content of ascorbic acid, carbohydrates and protein in stem and root of Tridax

\begin{tabular}{|l|c|c|}
\multicolumn{3}{|c|}{ procumbens } \\
\hline Name of the nutrient content (g/100g) & Name of plant parts \\
\cline { 2 - 3 } & Stem & Root \\
\hline Protein & $12 \pm 1.6$ & $11 \pm 1.9$ \\
\hline Carbohydrates & $23 \pm 2.5$ & $40 \pm 2.8$ \\
\hline Ascorbic acid & $0.0368 \pm 0.87$ & $0.0075 \pm 0.48$ \\
\hline
\end{tabular}

Values are expressed as mean \pm standard deviation of triplicates

The role of carbohydrates is to provide energy, as they are the body's main source of fuel for physical activity, brain function and operation of the organs. All the cells and tissues in our body need carbohydrates, and they are also important for intestinal health and waste elimination. Once in the body, carbohydrates are easily converted to fuel. Proteins also play a central role in biological processes. For example, proteins catalyze reactions in the system, transport molecules such as oxygen, keep healthy as part of the immune system and transmit messages from cell to cell. The water soluble vitamin $\mathrm{C}$ is functioning as enzyme cofactors and its deficiency leads to scurvy [18]. Amongst the biological activities of flavonoids are actions against free radicals, free radical mediated cellular signaling, inflammation, allergies, platelet aggregation, microbes, ulcers, viruses, tumors and hepatotoxins [19]. Phenolic acids are powerful antioxidants and have been 
reported to demonstrate antibacterial, antiviral, anti-carcinogenic, anti-inflammatory and vasodilatory actions [20].

For centuries plants have been used for both nutritional and medicinal purposes. In conventional medicine is not cheap and a large population of the people depends on traditional medicine for their healthcare needs. Over the years, these herbal drugs have been shown to be effective [21]. Many plants and their parts are used for the treatment of various diseases in different parts of the world, and are being screened for antimicrobial activities and the results obtained from these scientific studies have aided in the rationalization of medicinal use of these plants [22].

\section{Conclusion}

The present study confirmed that the presence of phytocompounds and nutrient contents like carbohydrates, protein and vitamin. The phytocompounds in Tridax procumbensmay be take part in the therapeutic properties.

\section{Acknowledgement}

The authors are thankful to the Principal, Government Arts college (Autonomous), Kumbakonam - 612 002, Tamilnadu, India for granting permission and also thankful to the authorities of Research Laboratory, Department of Biochemistry, Government Arts College (Autonomous), Kumbakonam - 612 002, Tamil nadu, India, for provided facilities to do this research work.

\section{Competing Interest}

Authors declare that no competing interests exist.

\section{References}

[1] Gaikwadi, Vadlamudi, Waghmaee, V.P., Maral, S.P., Ranteke, V.J. and Dhok, V.D. (2003). Phytochemical analysis of aqueous extract of few medicinal plants. Journal of Ethnopharrmacology., 2: 91-92.

[2] Sahoo, M. and Chand P. K. (1998). In vitro multiplication of a medicinal herb Tridax procumbens (Mexican Daisy, coat button): influence of explanting season, growth regulator synergy, culture passage and planting substrate. Phytomorphology., 48: 195 - 206.

[3] Meskin. and Mark, S. (2002) Phytochemicals in Nutrition and Health. CRC Press. p. 123.Global J. Pure Appl. Sci., 8b: 203- 208.

[4] Gaikwadi, Vadlamudi, Waghmaee, V.P., Maral, S.P., Ranteke, V.J. and Dhok, V.D. (2003). Phytochemical analysis of aqueous extract of few medicinal plants. Journal of Ethnopharrmacology., 2: 91-92.

[5] Suseela, L., Sarsvathy, A. and Brindha, P. (2002). Pharmacolognostic studies on Tridax procumbens L. Journal of Phytological Research., 15: 141-142.

[6] Tiwari, U., Rastogi, B., Singh, P., Saraf, D.K. and Vyas, S.P. (2004). Immunomodulatory effects of aqueous extract of Tridax procumbens in experimental animals. Journal of Ethanopharmacology., 9: 113-119.

[7] Trease, G.E. and Evans, W.C. (1983). Textbook of Pharmacognosy. 12th Edition, Tindall and Co., London, 343-383.

[8] Harborne, J.B. (1973). Phytochemical methods, Chapman and Hall, Ltd., London, pp. 49-188. 
[9] Wagner, H.M., Bladt, S. and Zgainski, E.M. (1984). Plant drug analysis. New York: springerverlag. p320.

[10] Ranganna, S. (1976). Handbook of analysis of quality control for fruits and vegetable product. 2nd Edn. Tata McGraw Hill Publication Company, New Delhi, India. Pages: 545.

[11] Roe, J. H. (1955). The Determination of sugar in blood and spinal fluid with anthrone reagent. J. Biol. Chem., 212(1): 335-43.

[12] Lowry, O. H., Rosebrough, N. J., Farr, A. L. and Randall, R. J. (1951). Biochem., 193: 265 - 273.

[13] Tabuti, J.R.S., lye, K.A. and Dhillion, S.S. (2003). Traditional herbal drugs of Bulamogi, Uganda: plants, use and administration. J. of Ethnopharmacology., 88:19-44.

[14] Gibson, E.L., Wardel, J. and Watts, C.J. (1998). Fruit and vegetable consumption, nutrition knowledge and beliefs in mothers and children. Journal of Pharmacology and Phytochemistry., 31 : $205-228$.

[15] Kappers, I.F., Aharoni, A., Van Herpen, T.W., Luckerhoff, L.L. and Dicke, M. (2005). Genetic engineering of terpeniod metabolism attracts bodyguard to Arabidopsis. Bioscience., 309: 20702072.

[16] Galeotti, F., Barile, E., Curir, P., Dolci, M. and Lanzotti, V. (2008). Flavonoids from carnation (Dianthus caryophyllus) and their antifungal activity. Phytochemistry Letters., 1: 44-48.

[17] Farinola, N. and Piller, N. (2005). PharmacogenomicsIts role in re-establishing coumarin as treatment for lymphedema. Lymphatic Research and Biology., 3(2): 81-86.

[18] Murray, R., Seifert, J. G., Eddy, D. E., Paul, G. L. and Halaby, G.A. (1989). Carbohydrate feeding and exercise: effect of beverage carbohydrate content. European Journal of Applied Physiology., 59: $152-158$.

[19] Dillard, C.J. and German, J.B. (2000). Phytochemicals: Nutraceuticals and Human Health. Journal of the Science of Food and Agriculture., 80: 1744-1756.

[20] Mattila, P. and Hellstrom, J. (2006). Phenolic Acids in Potatoes, Vegetables, and Some of Their Products. Journal of Food Composition and Analysis., 20(3-4): 152-160.

[21] Awe, S. and Omojalasola, P.F. (2003). Antibacterial screening of three medicinal plants used for diarrhea treatment in Ilorin, Nigeria. Nig. J. Pure and Appl. Sci., 1: 1375-1379.

[22] Abo, K.A., Ogunleye, V.O. and Ashidi, J.S. (1999). Antimicrobial Potential of Spondias mombin, Croton zambesicus and Zygotritonia crocea. Phytother. Res., 13(6): 494-497.

*Corresponding author.

E-mail address: udayabiochem@ yahoo.co.in 